\title{
Evaluation of White Half Runner' Green Bean Breeding Lines for Yield, Quality, and Disease Resistance
}

\author{
Charles A. M ullins, ${ }^{1}$ \\ R. Allen Straw, ${ }^{1}$ \\ J. Rennie Stavely, ${ }^{2}$ and \\ Jim Wyatt ${ }^{3}$
}

AdDitional INDEX words. rust, virus, pod crops, disease resistance, plant breeding, cultivars, pod quality

Summary. 'White H alf Runner' is a popular green bean (Phaseolusvulgaris L.) cultivar in the southern Appalachian region of the $U$ nited States. The cultivar is highly susceptible to rust and virus diseases. $\mathbf{N}$ ine breeding lines with 'White H alf Runner' parentage were compared to 'White $\mathrm{H}$ alf Runner' for rust tolerance, yield, and pod quality in 1998 and 1999 field trials at Crossville, Tenn. The BelT enn selections were developed by U SD A plant breeders and the U T selections were developed by U niversity of T ennessee plant breeders. Selections 'BelT enn-R R-2', 'BelT enn 4-12028', 'BelT enn 4-12046', 'BelT enn 4-12053', 'BelTenn 5-2717' and 'U T-96-3' were resistant to rust. O nly 'U T 96-4' had lower yields than 'White H alf R unner' in 1999. The BelT enn lines had slightly smaller pods, and the $U \mathrm{~T}$ selections had larger and rougher pods than 'White $H$ alf R unner'. 'BelTenn-R R-2' was

The cost of publishing this paper was defrayed in part by the payment of page charges. U nder postal regulations, this paper therefore must be hereby marked advertisement solely to indicate this fact.

${ }^{1} U$ niversity of Tennessee, Plant and Soil Science D epartment, Plateau Experiment Station, 320 Experiment Station Road, Crossille, TN 38555.

2U SD A-ARS, M olecular Plant Pathology L aboratory, Room 252, Bldg. 001A BARC-W., Beltsville, MD 20705-2350.

${ }^{3} U$ niversity of T ennessee, Plant and Soil Science D ept. West T ennesseeE xperiment Station 605 Airways BIvd. Jackson, TN 38301. 
released in 1995 as a breeding line with rust resistance and pod quality similar to 'White H alf R unner'. F urther selection of BelT enn-RR-2 by a private seed company led to the naming of a cultivar named 'V olunteer White H alf R unner'.

W hite $\mathrm{H}$ alf Runner has been a popular greenbean cultivar in the southern Appalachian region of the $U$ nited States for many years. Prices for 'W Wite $\mathrm{H}$ alf Runner' beans are usually much higher than prices for bush stringless beans. Production costsareal so greater for 'White $\mathrm{H}$ alf Runner as harvest is usually by hand. 'White H alf Runner' plants have a medium length runner, but are usually grown as a bush bean. $\mathrm{H}$ owever, production is greater when the plants are grown as a pole bean. Someproducersuseblack plastic mulch and drip irrigation to further enhance production and quality. 'White $\mathrm{H}$ alf Runner' pods have a distinctive flavor, which is more desirable in southern food preparation. The pods have a string that must be removed before they can be used, which is rather time consuming. The string eliminates the usage of 'White $\mathrm{H}$ alf Runner' as a commercial processing bean. 'White $H$ alf Runner' beans do not have a highly concentrated pod set. $\mathrm{H}$ and harvests may be once-over, but often three or four harvests are made for high yields and optimum pod quality. Some Tennessee producers machine harvest 'W hite H alf R unner' pods, but breakage and trash in the form of leaves are somewhat excessive in the harvested pods. Separating usable whole pods from the trash and broken pods is a labor intensive endeavor.

Plants of 'White Half Runner' bean are highly susceptible to diseases, especially bean rust (U romyces appendiculatus (Pers.: Pers.) U nger) and viruses. 'White $\mathrm{H}$ alf Runner' was used as a rust susceptible check cultivar in eastern U .S. regional rust trials, and had severe rust infestation at most trial locations (Stavely, 1999). N umerous strains of rust have been identified and certain strains commonly found in the eastern U .S. attack 'White H alf Runner'. The problem is very severe in the late fall season in Tennessee and surrounding states. The numbered selections have not been tested under severe virus conditions and their virus tolerance has not been determined. H owever, laboratory tests have indicated that the BelT enn selections are homozygous for the I gene for resistance to common bean mosaic virus.

Eight to ten named strains of 'White H alf Runner' bean are available, most notably 'M ountaineer' and 'State' (Reddick and Schwartz, 1987). N o known breeding effortsto improve the cultivar had been conducted for several years prior to 1990 . Breeding programswere initiated independently by U niversity of T ennessee researchers using 'State White $\mathrm{H}$ alf Runner' as a parent line and U SD A researchers using 'M ountaineer White H alf Runner' as a parent line. The objective of each program was to incorporate disease tolerance into 'White $\mathrm{H}$ alf Runner' type selections. 'White H alf Runner' was crossed with bush and pole beans with varying degrees of rust and virus tolerance, and several backcrosseswere made. O ver 100 selections from the crosses of each program were evaluated in initial field screening trials at The U niversity of T ennessee Plateau Experiment Station at $\mathrm{C}$ rossville, Tenn. A major objective was to maintain 'White $\mathrm{H}$ alf R unner' flavor and incorporate as much disease resistance as possible into the selections. Informal taste tests were a part of the selection process, and lines were selected based on flavor similar to 'White $\mathrm{H}$ alf Runner'. A secondary objective was to select for possible lines with a bush type plant growth habit and a stringless 'W hite $\mathrm{H}$ alf R unner' type pod for adaptability to machine harvest and commercial processing. M any selections were eliminated, and in 1995, three of the superior selections from the U SDA program were released as rust resistant breeding lines. Several lines remaining from each program wereevaluated in sequential trials. $\mathrm{N}$ ine numbered selectionswere evaluated in performance trials at C rossvillein 1998 and 1999

The objective of this study was to compare yield, plant and pod quality, and diseasetolerance of theninebreeding lines to 'White $\mathrm{H}$ alf Runner'. The testswere conducted in the fall season, when rust infestation was expected to be most severe.

\section{Materials and methods}

'WhiteH alf Runner' breeding line performance trials of the nine lines were conducted in 1998 and 1999 at
Crossville. 'White $\mathrm{H}$ alf Runner' was included in the trials as the check cultivar. 'BelT enn-RR-2', a superior breeding line release, was used for comparison to the newer selections. Single row plots $10 \mathrm{ft}(3.65 \mathrm{~m})$ long and $3 \mathrm{ft}(0.9 \mathrm{~m})$ wide were established. Within row spacing was approximately 2 inches $(5.1 \mathrm{~cm})$. Planting date was 25 J une 1998 and 21 J une 1999. Plots were arranged in a randomized complete-block design with four replications. The bean selections were grown unstaked following current recommendations. M etolachlor was applied preemergence at $2 \mathrm{lb}$ a.i./ acre (2.24 $\left.\mathrm{kg} \cdot \mathrm{ha}^{-1}\right)$ for weed control in 1998 and one cultivation was made in 1999 for weed control. O ne application of a recommended insecticide was made at full bloom each year. O verhead irrigation was used to provide 0.5 inches $(1.25 \mathrm{~cm})$ of water on 11 Sept. 1998.

$\mathrm{H}$ arvest was once-over by hand on 23 Sept. 1998 and 29 Sept. 1999. Snap beans are usually harvested when the center seed from ten of the most maturepodstotal 3.5 to 3.9 inches $(90$ to $100 \mathrm{~mm}$ ) in length. Pods in this study were harvested at a more mature stage, and when the center seed from ten of the most mature pods totaled 4.5 to 4.9 inches ( 115 to $125 \mathrm{~mm}$ ) in length which is near commercial harvest maturity for this type of green bean. 'W hite $\mathrm{H}$ alf R unner' pods have a larger seeds than most green beans, but the pods remain ten der when seeds are relatively large. Plant height and plant width measurements, and leaf rust ratingsweremade at harvest. Yields were recorded at harvest, and pod length and diameter of 25 pods per plot were measured soon after harvest. R atings were made for pod curvature and smoothness, and notes were made on conformity of fresh and cooked pods to 'White $\mathrm{H}$ alf R unner'.

All dataweresubjected to analysis of variance and Duncan's multiple range test $(\alpha=0.05)$ (SAS, 1987). Since some variables were significantly different due to year, data will be presented for individual years.

\section{Results}

The plant type of all breeding line selections was very similar to 'White $\mathrm{H}$ alf Runner', and plant height of all lines was near 16 inches $(40.6 \mathrm{~cm})$ both years. $D$ ifferencesin plant height, width, and type of growth habit were not visually apparent due to selection. 
Table 1. R ust ratings and yields of 'White $H$ alf $R$ unner' and related breeding lines at C rossville, Tenn., 1998-99.

\begin{tabular}{|c|c|c|c|c|}
\hline \multirow[b]{2}{*}{ Selection } & \multicolumn{2}{|c|}{$\begin{array}{l}\text { R ust rating } \\
(\%)^{z}\end{array}$} & \multicolumn{2}{|c|}{$\begin{array}{l}\text { Pod yield } \\
\text { (bushel/acre)y }\end{array}$} \\
\hline & 1998 & 1999 & 1998 & 1999 \\
\hline White $\mathrm{H}$ alf R unner & $20 a^{x}$ & $65 \mathrm{~b}$ & $121 \mathrm{a}$ & $302 a b$ \\
\hline BelTenn-RR-2 & $0 \mathrm{~b}$ & $0 \mathrm{e}$ & 146 a & $313 a b$ \\
\hline BelTenn 4-12028 & $0 \mathrm{~b}$ & $0 \mathrm{e}$ & 136 a & $265 b c$ \\
\hline BelT enn 4-12046 & $0 \mathrm{~b}$ & $0 \mathrm{e}$ & $137 \mathrm{a}$ & $313 a b$ \\
\hline BelTenn 4-12053 & $0 \mathrm{~b}$ & $0 \mathrm{e}$ & 146 a & $311 a b$ \\
\hline BelT enn 5-2717 & $0 \mathrm{~b}$ & $0 \mathrm{e}$ & 157 a & $300 a b$ \\
\hline UT 96-1 & $23 a$ & 75 a & 173 a & 266 bc \\
\hline UT 96-2 & 35 a & $53 c$ & $235 a$ & $334 a b$ \\
\hline UT 96-3 & $0 \mathrm{~b}$ & $2 \mathrm{e}$ & 162 a & $355 a$ \\
\hline UT 96-4 & $0 \mathrm{~b}$ & $25 d$ & 149 a & $227 \mathrm{c}$ \\
\hline
\end{tabular}

zPercentage leaf surface covered by rust symptoms.

y umber of bushel [30- $\mathrm{lb}(13.6-\mathrm{kg})]$ boxes per acre; 1 bushel $/ \mathrm{acre}=33.6 \mathrm{~kg} \cdot \mathrm{ha}^{-1}$.

${ }^{x} \mathrm{M}$ eans in the same column followed by the same letter are not significantly different $(P=0.05)$, according to D uncan's multiple range test.

T able 2. Pod length and diameter of 'White $H$ alf Runner' and related breeding lines at C rossville, Tenn., 1998-99.

\begin{tabular}{llllll}
\hline & \multicolumn{2}{c}{$\begin{array}{c}\text { Pod length } \\
\text { (inches) }^{\mathbf{z}}\end{array}$} & & \multicolumn{2}{c}{$\begin{array}{c}\text { Pod diam } \\
\text { (inches) }\end{array}$} \\
\cline { 2 - 3 } Selection & $\mathbf{1 9 9 8}$ & $\mathbf{1 9 9 9}$ & & $\mathbf{1 9 9 8}$ & $\mathbf{1 9 9 9}$ \\
\hline White H alf Runner & $3.7 \mathrm{ab}^{\mathrm{y}}$ & $4.7 \mathrm{a}$ & & $0.46 \mathrm{~b}$ & $0.49 \mathrm{ab}$ \\
BelT enn-RR-2 & $3.8 \mathrm{ab}$ & $4.5 \mathrm{ab}$ & & $0.45 \mathrm{~b}$ & $0.45 \mathrm{C}$ \\
BelTenn 4-12028 & $3.5 \mathrm{~b}$ & $4.0 \mathrm{e}$ & & $0.45 \mathrm{~b}$ & $0.45 \mathrm{C}$ \\
BelTenn 4-12046 & $3.5 \mathrm{~b}$ & $4.0 \mathrm{e}$ & & $0.45 \mathrm{~b}$ & $0.45 \mathrm{C}$ \\
BelT enn 4-12053 & $3.6 \mathrm{ab}$ & $4.3 \mathrm{bcd}$ & & $0.45 \mathrm{~b}$ & $0.48 \mathrm{abc}$ \\
BelTenn 5-2717 & $3.8 \mathrm{ab}$ & $4.1 \mathrm{de}$ & & $0.44 \mathrm{~b}$ & $0.46 \mathrm{bc}$ \\
UT 96-1 & $4.0 \mathrm{a}$ & $4.4 \mathrm{~b}$ & & $0.50 \mathrm{a}$ & $0.50 \mathrm{a}$ \\
UT 96-2 & $4.0 \mathrm{a}$ & $4.4 \mathrm{~b}$ & & $0.51 \mathrm{a}$ & $0.49 \mathrm{ab}$ \\
UT 96-3 & $4.0 \mathrm{a}$ & $4.4 \mathrm{~b}$ & & $0.51 \mathrm{a}$ & $0.50 \mathrm{a}$ \\
UT 96-4 & $3.9 \mathrm{ab}$ & $4.2 \mathrm{cde}$ & & $0.44 \mathrm{~b}$ & $0.45 \mathrm{C}$ \\
\hline
\end{tabular}

${ }^{2} 1$ inch $=2.54 \mathrm{~cm}$, measurements of most mature pods.

yM eans in the same column followed by the same letter are not significantly different $(P=0.05)$, according to D uncan's multiple range test.

T able 3. Pod smoothness and curvature ratings of 'W hite $H$ alf $R$ unner' and related breeding lines at C rossville, T enn., 1998-99.

\begin{tabular}{llllll}
\hline & \multicolumn{2}{c}{$\begin{array}{c}\text { Pod smoothness } \\
\text { rating }\end{array}$} & & \multicolumn{2}{c}{$\begin{array}{c}\text { Pod curvature } \\
\text { rating }\end{array}$} \\
\cline { 2 - 3 } \cline { 6 - 7 } Selection & $\mathbf{1 9 9 8}$ & $\mathbf{1 9 9 9}$ & & $\mathbf{1 9 9 8}$ & $\mathbf{1 9 9 9}$ \\
\hline White H alf Runner & $4.0 \mathrm{a}^{\mathrm{z}}$ & $3.8 \mathrm{c}$ & & $4.08 \mathrm{abcd}$ & $4.05 \mathrm{~cd}$ \\
BelTenn-RR-2 & $4.1 \mathrm{a}$ & $3.8 \mathrm{c}$ & & $4.25 \mathrm{a}$ & $4.10 \mathrm{bcd}$ \\
BelTenn 4-12028 & $3.7 \mathrm{abc}$ & $4.0 \mathrm{a}$ & & $4.15 \mathrm{abc}$ & $4.50 \mathrm{a}$ \\
BelT enn 4-12046 & $3.9 \mathrm{ab}$ & $4.0 \mathrm{a}$ & & $4.20 \mathrm{ab}$ & $4.20 \mathrm{abcd}$ \\
BelTenn 4-12053 & $4.0 \mathrm{a}$ & $4.9 \mathrm{a}$ & & $4.23 \mathrm{a}$ & $4.43 \mathrm{abc}$ \\
BelT enn 5-2717 & $3.8 \mathrm{ab}$ & $4.0 \mathrm{ab}$ & & $4.20 \mathrm{ab}$ & $4.50 \mathrm{a}$ \\
UT 96-1 & $3.3 \mathrm{~d}$ & $4.0 \mathrm{ab}$ & & $4.00 \mathrm{bcd}$ & $4.45 \mathrm{ab}$ \\
UT 96-2 & $3.4 \mathrm{~cd}$ & $3.8 \mathrm{c}$ & & $3.98 \mathrm{~cd}$ & $4.05 \mathrm{~cd}$ \\
UT 96-3 & $3.5 \mathrm{bcd}$ & $3.4 \mathrm{~d}$ & & $3.90 \mathrm{~d}$ & $3.83 \mathrm{~d}$ \\
UT 96-4 & $3.9 \mathrm{ab}$ & $4.0 \mathrm{a}$ & & $3.90 \mathrm{~d}$ & $4.00 \mathrm{~d}$
\end{tabular}

2Ratings on a scale of 1 to 5, 5 = most acceptable.

yM eans in the same column followed by the same letter are not significantly different $(P=0.05)$, according to D uncan's multiple range test.
No lines with bush plant type and stringless 'White $\mathrm{H}$ alf Runner' type pods were observed in plant populations from the original crosses.

Rust was more severe in 1999 than in 1998 (Table 1). Both growing seasons were relatively dry, but humidity was higher in 1999, which may account for the rust differencesamong years for the rust susceptible selections. The BelTenn selections have parentage from U SD A bean lines that are immune to all known rases of rust. The BelTenn selections did not develop any rust in either year of the study. They are classed as rust resistant lines. Plants of 'White $\mathrm{H}$ alf Runner', 'UT 96-1', and 'UT 96-2' had significantly more in both years of the trials than the resistant selections. Plants of 'UT 96-4' developed significantlymore rust in 1999, and plants of 'U T 96-3' were comparable to the resistant lines in both seasons.

Yields were not significantly different due to selection in 1998 (T able 1). Line 'UT 96-3' produced higher yields than 'BelT enn 4-12028', 'UT 96-1', and 'UT 96-4', and only 'UT 96-4' had lower yields than 'White $\mathrm{H}$ alf R unner' in 1999. Theother numbered selections maintained the relatively high yield levels associated with 'White $\mathrm{H}$ alf Runner'.

'U T 96-1', 'UT 96-2', and “U T 96-3' had longer pods than 'BelT enn 4-12028', and 'BelT enn 4-12046 in 1998 (Table 2). 'White H alf Runner' had longer pods than all selections except 'BelT enn-RR-2' in 1999. Pods were longer in 1999 than in 1998, probably due to differences in weather conditions. Stress from heat and/ or drought usually results in a shorter pod length of green beans. All selections including 'White $\mathrm{H}$ alf Runner' had relatively short pods for green snap beans which is usually in the 5 to 6 inch $(12.7$ to $15.2 \mathrm{~cm}$ ) range. Pod diameter was generally smaller for 'BelT enn-RR-2', 'BelT enn 4-12028', 'BelTenn 4-12046', and 'U T 96-4' than for most other selections.

Pods of 'White H alf Runner' are relatively bumpy and somewhat rough due to the large seed size attained in mature pods. Selections with the least smoothness in 1998 were 'U T 96-1', 'UT 96-2', and 'UT 96-3' (T able 3). Selectionswith theleast smoothnessin 1999 were 'White H alf Runner', 'BelT enn-RR-2', 'U T 96-2, and 'UT 96-3'. Pods of 'BelT enn-RR-2' and 
'BelT enn 4-12053' had less curvature than pods of 'UT 96-1', 'UT 96-2', 'UT 96-3', and 'UT 96-4' in 1998 (Table 3). Selections with the least curvature in 1999 were 'BelTenn 412028' and 'BelT enn 5-2717'.

\section{Conclusions}

Progress has been made in achieving rust resistancein several 'White H alf Runner' type green bean selections. Yields and pod characteristics of many of the breeding lines were similar to those of 'White H alf Runner'. The U T selections tended to produce slightly larger and rougher pods, and the BelT enn selections tended to have slightly shorter and smaller pods than 'White Half Runner'. None of the unreleased numbered selections had superior performance to 'BelT enn-RR2' which was released in 1995 as a rust resistant 'WhiteH alfR unner' typebreeding line. 'BelTenn-RR-2' was evaluated in limited commercial grower and home gardenertrial sfrom 1994 through 1997. A selection of 'BelT enn-RR-2' was increased by a commercial seed company and was released as 'Volunteer White H alf Runner'. 'V olunteer White $\mathrm{H}$ alf Runner' performed well in grower trialsin T ennessee, $\mathrm{N}$ orth C arolina, and Virginia in 1999, and appeared to have considerable commercial potential as a rust resistant ' White $\mathrm{H}$ alf Runner' type cultivar. A limited supply of seed was available commercially for 2000 and seed availability should increase in future years if the cultivar is successful.

\section{Literature cited}

Reddick, B. and K. Schwartz. 1987. Reactions of $\mathrm{H}$ alf Runner snap beans to virus infection. Tenn. Farm H ome Sci. 143:2223.

Stavely, R. 1999. Bean rust in the U nited States in 1998. Annu. Rpt. Bean I mprovement Coop. 42:113-114. 